\title{
Identification and Characterization of Rat 364-kDa Golgi-associated Protein Recognized by Autoantibodies from a Patient with Rheumatoid Arthritis
}

\author{
Chie Toki ${ }^{1}$, Toshiyuki Fujiwara ${ }^{1}$, Miwa Sohda ${ }^{1}$, Hong-Shang Hong ${ }^{2}$, Yoshio Misumi ${ }^{1}$, and Yukio \\ Ikehara ${ }^{*}$ \\ ${ }^{1}$ Department of Biochemistry, Fukuoka University School of Medicine, Nanakuma, Jonan-ku, Fukuoka 814- \\ 80; and ${ }^{2}$ Department of Dermatology, Chang Gung Memorial Hospital, Tung Hwa North Road, Taipei, \\ Taiwan R.O.C.
}

Key words: autoantibody/cDNA cloning/coiled-coil structure/GCP364/giantin family/Golgi-associated proteins

\begin{abstract}
$A B S T R A C T$. Autoantibodies from a patient with rheumatoid arthritis recognized an antigen localized in the Golgi complex of various cells tested. The autoantibodies were used as a probe for screening rat NRK cDNA library, resulting in identification of an $11 \mathrm{kbp}$ cDNA. The cDNA contained an open reading frame which encodes a 3,187-residue protein with a calculated mass of $364 \mathrm{kDa}$. The predicted protein, GCP364 (for a Golgi complex-associated protein of $364 \mathrm{kDa}$ ), was found to have no $\mathrm{NH}_{2}$-terminal signal sequence but a single hydrophobic domain at the $\mathrm{COOH}$ terminus and characteristically contain many coiled-coil domains with various sizes throughout the entire sequence. The identity of GCP364 with the autoantigen was confirmed by immunofluorescence and immunoblot analysis with the autoantibodies and anti-recombinant GCP364 produced in rabbits and by transfection/expression experiments. Search for the protein sequence data base revealed that GCP364 has $75 \%$ identity in amino acid sequence with human GCP372/giantin, indicating that it is a rat homolog of the latter. Immunogold electron microscopy showed that GCP364 was not detected on coated vesicles derived from the Golgi membrane, suggesting no involvement in the formation of transport vesicles. When cells were perforated and incubated with anti-GCP364 serum, the Golgi complex localized at perinuclear regions was dispersed into fragment-like structures as observed in nocodazole-treated cells. Taken together, these results suggest that GCP364 is anchored to the membrane by the COOH-terminal hydrophobic domain and has an extremely long cytoplasmic domain with coiled-coil structures, which may be involved in the formation and/or maintenance of the characteristic Golgi structure.
\end{abstract}

The Golgi apparatus is a highly organized complex with structurally and functionally distinct subcompartments including the cis-Golgi network (CGN), the Golgi stack and the trans-Golgi network (TGN). The Golgi stack is comprised of the cis-, medial and transcisternae. The Golgi complex plays an important role in transport, processing and sorting of proteins synthesized in the endoplasmic reticulum (ER).

Protein transport through these Golgi subcompartments is believed to be mediated by small vesicles. Recent studies have identified a number of cytosolic and

\footnotetext{
* To whom correspondence and reprint requests should be addressed.

Abbreviations: ARF, ADP-ribosylation factor; COP, coat protein complex (coatomer); ER, endoplasmic reticulum; GCP, Golgi complex-associated protein; GST, glutathione S-transferase; HRP, horseradish peroxidase; Man II, $\alpha$-mannosidase II; PNS, post-nuclear supernatant; RA, rheumatoid arthritis.

The nucleotide sequence of GCP364 has been deposited in the DDBJ/EMBL/GenBank Data Libraries under the accession number D25543.
}

membrane proteins involved in the vesicular transport $(33,34)$. These include coat protein complex (coatomer, COP I) and ADP-ribosylation factor (ARF) required for budding and formation of Golgi-derived transport vesicles, and $\mathrm{N}$-ethylmaleimide-sensitive fusion protein (NSF) and soluble NSF attachment proteins (SNAP) and SNAP receptors (SNARE) involved in the vesicle fusion. Available evidence indicates that the vesicular transport system functions not only in delivery of proteins to their final destinations but also in maintenance of the Golgi structure. Brefeldin A, initially found as a potent inhibitor of secretion $(11,23)$, is known to block the budding/formation of transport vesicles by inhibiting a GDP/GTP exchange of ARF which is essential for the attachment of ARF and COP I onto the Golgi membrane $(6,16,31)$. The inhibition of vesicular transport is accompanied by redistribution of resident Golgi components to the ER, resulting in disassembly of the Golgi stack $(11,12,21)$. The Golgi structure is reformed immediately after removal of the drug. These observations suggest that the Golgi structure is maintained by vesicu- 
lar transport-dependent supply of the resident Golgi components and their balanced recycling between the ER and the Golgi.

Despite these findings, the mechanism for vesicular transport alone may not be sufficient to explain the formation of the unique Golgi structure with the ordered stacking, close apposition and constant spacing of stacked cisternae. There must be other components, in addition to those involved in the vesicular transport, which would be responsible for the formation or structural arrangement of the subcompartments in the Golgi complex. Many investigators have attempted to identify such components by preparing antibodies to the Golgi complex or by autoantibodies in sera from patients with autoimmune diseases. Golgi-associated proteins including giantin (19), p210 (27) and GM130 (26) were identified by antibodies directed against the purified Golgi complex, while a 79-kDa protein (17), golgin-95 and golgin-160 (8), p210 (32), GCP230 (13), golgin-245/p230 $(7,9)$ and GCP372 $(41)$ were characterized by the autoantibodies. Most of these proteins are peripheral proteins loosely $(7-9,13,27,32)$ or tightly (26) associated with the Golgi membrane, while giantin and GCP372 are integral membrane proteins $(1,41)$. A structural similarity of the latter two indicates that GCP372 is an isoform of giantin $(37,41)$.

In this study we have identified a $364-\mathrm{kDa}$ protein (GCP364) associated with the Golgi complex which was recognized by autoantibodies from a patient with rheumatoid arthritis (RA) and isolated its cDNA clones from a rat NRK cDNA library. The primary and secondary structures predicted by the cDNA sequence and coiled-coil probability, respectively, indicate that GCP364 is a member of the GCP372/giantin family.

\section{MATERIALS AND METHODS}

Materials. A serum containing anti-Golgi autoantibodies was obtained from a Chinese patient with rheumatoid arthritis (RA). Cy2-conjugated goat anti-human IgG was from Biological Detection Systems Inc. (Pittsburgh, PA); horseradish peroxidase (HRP)-conjugated goat anti-human IgG was from Bio-Rad (Richmond, CA); rhodamine- or HRP-conjugated goat anti-rabbit IgG was from DAKO Japan (Tokyo); monoclonal anti-rat $\alpha$-mannosidase II (Man II) and goat anti- $\alpha$-tubulin antiserum were from Funakoshi (Tokyo). Rabbit antirat Man II was supplied by Dr. K. Moremen (University of Georgia). Anti- $\beta$-COP antibodies were raised in rabbits (38). ECL Western blotting detection kit was obtained from Amersham Japan (Tokyo). Various DNA-modifying enzymes and restriction endonucleases were purchased from Toyobo Biochemicals (Osaka), Takara Shuzo (Kyoto) and Nippon Gene (Toyama, Japan).

Cell Culture. NRK (rat kidney), COS-1 (monkey kidney) and HepG2 (human hepatoma) cells were cultured as de- scribed previously (41).

Isolation and Sequencing of $c D N A$ Clones. A poly(A) ${ }^{+}$ RNA fraction prepared from NRK cells was used for construction of the cDNA library in $\lambda$ ZAPII bacteriophage, which was subjected to screening with the autoantibodies as described previously (24). Screening of $2 \times 10^{6}$ independent clones with the autoantibodies yielded 10 positive clones. After plaque purification, the cDNAs were subcloned into the pbluescriptSK ${ }^{-}$ plasmid vector by auto-excision process and analyzed by restriction endonuclease mapping. A 5' 900-bp fragment of the cDNA clone which had the longest insert $(6.1 \mathrm{kbp})$ was used as a probe for further screening of the library by the plaque hybridization method (30), and 15 positive clones were obtained. All the positive clones were sequenced by the dideoxynucleotide chain termination method (35) using synthesized oligonucleotides as primers.

Northern Blot Analysis. Total RNA and poly(A) ${ }^{+}$RNA prepared from NRK cells were separated by formamide-formaldehyde agarose gel electrophoresis, blotted to a Hybond $\mathrm{N}$ membrane filter and probed with a mixture of ${ }^{32} \mathrm{P}$-labeled EcoRI-AflII fragment $(1.4 \mathrm{~kb})$ of AGP1326 and HindIIIHindIII fragment (1.6 kb) of AGM24 (see Fig. 2).

Construction, Transfection and Expression of the Complete GCP364 cDNA. A cDNA covering the entire coding region of GCP364 was constructed from the three cDNA clones AGM24, AGP25 and AGP1326 (see Fig. 2). An internal EcoRI site of AGM24 was initially destroyed by site-directed mutagenesis without changing the amino acid sequence. A major XbaI-KpnI fragment of AGP25 was ligated to the KpnI site of the mutated AGM24. A 5 -terminal fragment of AGP1326 was prepard by digestion with $\mathrm{XbaI}$ and ligated to the XbaI site of the above construct. The cDNA thus constructed (pGCP364) was inserted into the EcoRI site of pSG5 expression vector and designated pGCP364/pSG5. The pGCP364/pSG5 $(20 \mu \mathrm{g})$ purified by $\mathrm{CsCl}_{2}$-gradient centrifugation was transfected into COS- 1 cells $\left(5 \times 10^{6}\right.$ cells) using an electro-poration apparatus (Gene Pulser, Bio-Rad) (25). After $24 \mathrm{~h}$ of culture, cells were subjected to immunohistochemical and immunoblot analyses.

Production of Anti-recombinant GCP364 Antibodies. The three cDNA fragments F-1, F-2 and F-3 (see Fig. 2) were prepared by digestion of the indicated cDNA clones with appropriate restriction endonucleases; F-1 was an EcoRIStuI fragment derived from AGP25 (1293-1923 in pGCP364 nucleotide number); F-2, an EcoRI-EcoRV fragment from AGP2808 (4356-5729); and F-3, an EcoRV-HindIII fragment from AGM24 (5730-7915). Each fragment was inserted into an appropriate site of $\mathrm{pGEX}-2 \mathrm{~T}$ vector for production of fusion proteins with glutathione S-transferase (GST). Expression and purification of the GST-fusion proteins were performed according to the method of Smith and Johnson (40). Anti-recombinant GCP364 (rGCP364) antibodies were raised in rabbits by injecting a mixture of the three recombinant proteins $(200 \mu \mathrm{g}$ each protein/injection/rabbit) several times every two weeks. Antibodies against GST in the fusion pro- 
teins were removed by adsorption with GST-coupled Toyopearl 650 .

Immunocytochemistry. Immunofluorescence microscopy was carried out as described before (41). Briefly, cells were fixed with $4 \%$ paraformaldehyde, permeabilized with $0.1 \%$ saponin, and incubated with the indicated primary antibodies, followed by incubation with the indicated rhodamine- or Cy2conjugated secondary antibodies.

For immunoelectron microscopy, cells were fixed with the periodate-lysine-paraformaldehyde fixative for $2 \mathrm{~h}$ at room temperature. After being permeabilized as above, cells were incubated at room temperature with the autoantibodies and then with HRP-conjugated anti-human IgG antibodies. The peroxidase reaction was carried out at room temperature for $15 \mathrm{~min}$ in a substrate medium containing diaminobenzidiine $(0.5 \mathrm{mg} / \mathrm{ml})$ and $0.01 \% \mathrm{H}_{2} \mathrm{O}_{2}$. The cells were processed for electron microscopy as described previously (11).

For ultrathin cryosectioning and immunogold labeling, membrane pellets were fixed with $4 \%$ paraformaldehyde and $0.2 \%$ glutaraldehyde in $0.1 \mathrm{M}$ phosphate buffer ( $\mathrm{pH} 7.4$ ) containing $10 \%$ sucrose, cryoprotected by infiltration with $2.3 \mathrm{M}$ sucrose, and frozen in liquid nitrogen. Frozen sections (60$\mathrm{nm}$ ) were prepared and mounted on coated nickel grids. The sections were incubated with the indicated antibodies, then with Protein A-conjugated gold particles $(10 \mathrm{~nm})$, and processed for electron microscopy (41).

Immunoblotting. This was performed as described previously (14). Proteins were separated by SDS-PAGE (5\% gel) and transferred to an Immobilon PVDF membrane. The membrane was incubated with the autoantibodies serum at dilution of 1:500 or with anti-rGCP364 serum at dilution of 1:1000. HRP-conjugated anti-human IgG or anti-rabbit IgG antibodies at dilution of 1:2000 was used as secondary antibodies, and the membrane was processed for enhanced chemiluminescence (ECL kit).

Cell Fractionation and Membrane Extraction. Cells were homogenized in a solution containing $0.25 \mathrm{M}$ sucrose, $10 \mathrm{mM}$ Tris- $\mathrm{HCl}$ (pH 7.5) and $2 \mathrm{mM}$ EDTA (homogenizing buffer) in a nitrogen bombardment apparatus (Parr Instrument Co., IL), and the homogenate was centrifuged at $1,000 \mathrm{~g}$ for 10 min. The resultant supernatant was used as a postnuclear supernatant (PNS). Equal amounts of the PNS were centrifuged at $105,000 \mathrm{~g}$ for $1 \mathrm{~h}$ to obtain membrane pellets and supernatant (cytosol). The membranes were resuspended in the homogenizing buffer containing either $0.1 \mathrm{M} \mathrm{Na} \mathrm{CO}_{3}, 1 \%$ Triton X-100 or 1\% sodium deoxycholate. After being incubated on ice for $30 \mathrm{~min}$, the suspensions were centrifuged at $105,000 \mathrm{~g}$ for $30 \mathrm{~min}$ to obtain supernatants and membrane pellets.

In Vitro Accumulation of Golgi-derived Transport Vesicles. Golgi membranes (29) and cytosol (1) were prepared from rat liver and brain, respectively, and used for in vitro budding and formation of Golgi vesicles (31). The Golgi membranes $(200 \mu \mathrm{g}$ protein $/ \mathrm{ml})$ and cytosol $(2.3 \mathrm{mg}$ protein $/ \mathrm{ml})$ were incubated at $37^{\circ} \mathrm{C}$ for $30 \mathrm{~min}$ in $0.2 \mathrm{ml}$ of $0.2 \mathrm{M}$ sucrose containing $25 \mathrm{mM}$ Hepes-KOH (pH 7.2), $25 \mathrm{mM} \mathrm{KCl}, 2.5$ $\mathrm{mM}$ magnesium acetate and the ATP-regenerating system ( $0.25 \mathrm{mM}$ ATP, $10 \mu \mathrm{g} / \mathrm{ml}$ of creatine kinase and $2.5 \mathrm{mM}$ creatine phosphate) in the absence or presence of $20 \mu \mathrm{M}$ GTP $\gamma \mathrm{S}$. The membranes were pelleted, fixed and cryosectioned for immunogold labeling as described above.

Other Treatments of Cells. NRK cells were perforated as described previously (39). The perforated cells were incubated at $37^{\circ} \mathrm{C}$ for $1 \mathrm{~h}$ with anti-rGCP642 serum or non-immune serum (10\%) in $25 \mathrm{mM}$ Hepes-KOH (pH 7.2), $115 \mathrm{mM} \mathrm{KCl}$ and $2.5 \mathrm{mM}$ magnesium acetate (medium $\mathrm{A}$ ) containing rat brain cytosol $(5 \mathrm{mg} / \mathrm{ml})$ and the ATP-regenerating system $(0.5 \mathrm{mM}$ ATP, $5 \mathrm{mM}$ creatine phosphate and $50 \mu \mathrm{g} / \mathrm{ml}$ of creatine kinase). For depolymerization of microtubules, intact cells were incubated at $37^{\circ} \mathrm{C}$ for $1 \mathrm{~h}$ with $50 \mu \mathrm{M}$ nocodazole in the Dulbecco's minimum essential medium.

Computer Analysis of $c D N A$ and Protein. cDNA and protein sequences were analyzed by the GENETX genetic information processing software (Software Development Co., Tokyo) and FASTA program at the DNA Data Bank of Japan (Mishima, Japan). Coiled-coil graphs were made from data generated by COILS (ver. 2.1) algorithm of Swiss Cancer Research Institute (22). The MTDIK matrix and a window size of 28 residues were used.

\section{RESULTS}

Identification of a Golgi Antigen with Autoantibodies. A serum obtained from an RA patient was used for indirect immunofluorescence staining of rat NRK cells. A heavy staining with immunofluorescence was observed at perinuclear regions (Fig. 1A, a), where the Golgi marker $\alpha$-mannosidase II (ManII) was colocalized when the cells were double-stained with anti-ManII (Fig. 1A, b). The intracellular localization of the antigen was examined in more detail by immunoelectron microscopy. A positive reaction of the immunoperoxidase was detected at the Golgi complex with a characteristic stack structure (Fig. 1A, c). These observations indicate that the antigen recognized by the autoantibodies is localized at the Golgi complex. The autoantibodies were found to cross-react with various cells derived from other species including mouse, hamster, monkey, chicken as well as human (data not shown). Immunoblotting experiments showed that the autoantibodies recognized a protein with an apparent molecular mass of at least $300 \mathrm{kDa}$ in all cells examined, of which results with NRK, COS-1 and HepG2 cells were shown in Fig. 1B. $c D N A$ Cloning of the Golgi Antigen. We then isolated cDNA clones for the Golgi antigen from the NRK cDNA library. Screening of the library with the autoantibodies and subsequent screening by the plaque hybridization method yielded seven major cDNA clones with inserts longer than $3 \mathrm{kbp}$, which overlapped from each other and together spanned a stretch of about $10 \mathrm{kbp}$ of 
A
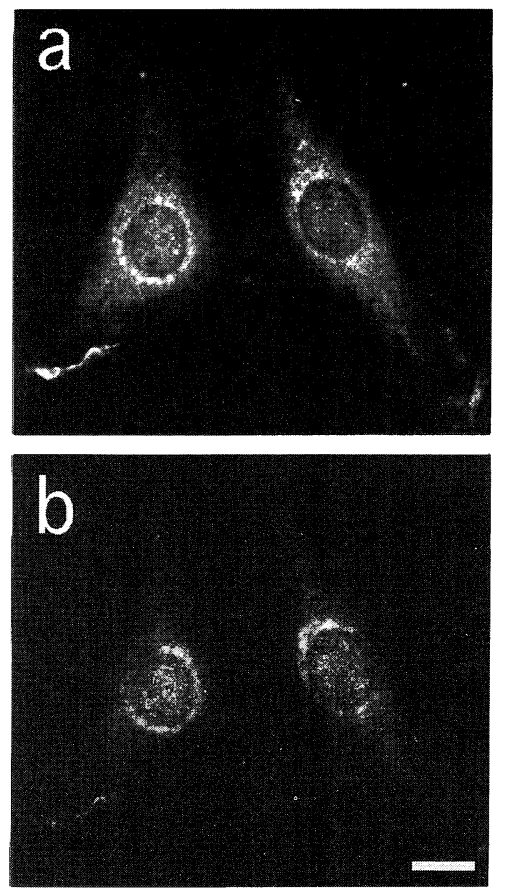
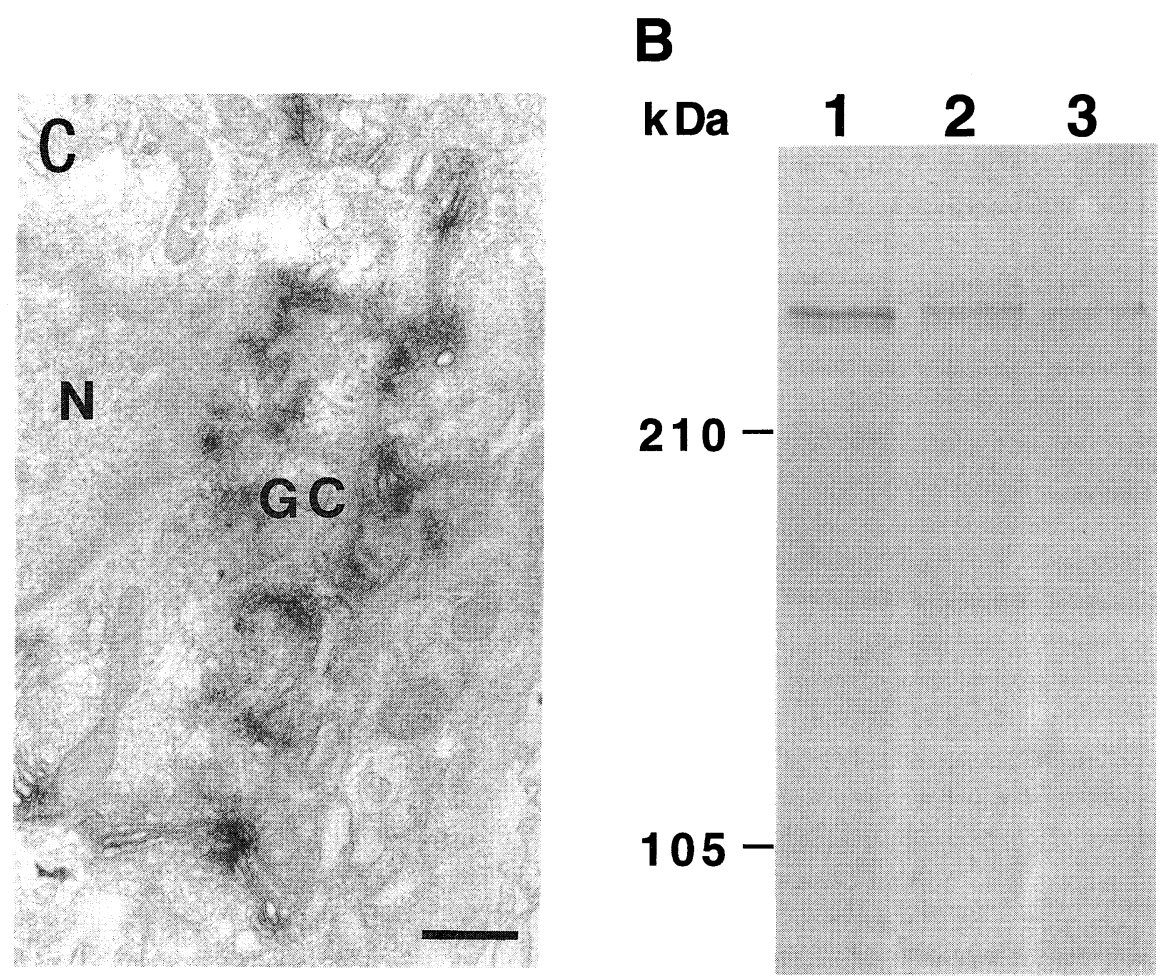

Fig. 1. Identification of a Golgi-associated antigen with autoantibodies from RA patient. (A) Immunofluorescence (panels a and b) and immunoelectron (c) microscopy of NRK cells. Cells were double-stained with the human autoantibodies (a) and with rabbit anti-Man II (b) which were visualized by incubation with Cy2-conjugated anti-human IgG and rhodamine-conjugated anti-rabbit IgG, respectively. Scale bar, $10 \mu \mathrm{m}$. In (c), cells were stained with the autoantibodies coupled with HRP-conjugated anti-human IgG. GC, Golgi complex; N, nucleus. Scale bar, $0.5 \mu \mathrm{m}$. (B) Immunoblot analysis. Cell lysates ( $30 \mu \mathrm{g} / \mathrm{lane}$ ) prepared from NRK (lane 1), COS-1 (lane 2) and HepG2 (lane 3) cells were separated by SDSPAGE (5\% gel), followed by immunoblotting with the autoantibodies. Molecular mass markers used are myosin heavy chain ( $215 \mathrm{kDa})$ and phosphorylase b (105 kDa).

DNA (Fig. 2). Total and poly(A) ${ }^{+}$RNA prepared from the NRK cells were blotted and probed with ${ }^{32} \mathrm{P}$-labeled cDNA fragments, which identified an RNA component of about $11 \mathrm{~kb}$ (Fig. 3). The value of $11 \mathrm{~kb}$ in the mRNA is in good agreement with that determined for the complete cDNA of the Golgi antigen.

Predicted Structure of the Golgi Antigen GCP364. The seven cDNA inserts were sequenced from multiple restriction sites and on both DNA strands. The combined nucleotide sequence (10,172 nucleotides) includes the $5^{\prime}$ noncoding region (291 nucleotides), the coding region $\left(9,561\right.$ nucleotides) and the $3^{\prime}$ noncoding region (320 nucleotides). The open reading frame encodes a protein of 3,187 amino acid residues with a calculated mass of $364 \mathrm{kDa}$ (Fig. 4). Here we designate this protein GCP364. The predicted amino acid sequence of GCP364 contains no hydrophobic domain at the $\mathrm{NH}_{2}$ terminus which serves as the translocation signal across the ER membrane, but has a single hydrophobic domain at the $\mathrm{COOH}$ terminus that could participate in membrane localization. The leucine zipper motif Leu$\mathrm{X}_{6}$-Leu- $\mathrm{X}_{6}$-Leu- $\mathrm{X}_{6}$-Leu and other heptad repeats are fre- quently seen in the entire sequence, predicting the formation of coiled-coil structures (22).

The deduced amino acid sequence of GCP364 was compared with the known protein sequences so far reported, demonstrating some similarity (18-22\% identity) with many filamentous proteins containing coiledcoil domains such as myosins, desmin and desmoplakin. The most striking similarity was found in human GCP372/giantin $(37,41)$, which had $77.7 \%$ (nucleotide sequence) and 75\% (amino acid sequence) identity with those of GCP364. The coiled-coil probability of GCP364 was compared with that of GCP372/giantin (Fig. 5). Almost the entire sequence of GCP364 is occupied by coiled-coil domains, which are interrupted by relatively long non-coil domains with more than $50 \mathrm{ami-}$ no acids at the both termini and at three sites between them (indicated by thick bars in Fig. 5A), although there are many other short interruptions. These features in the secondary structure are conserved in the human GCP372/giantin. The four major coiled-coil domains share $69-81 \%$ identity in the amino acid sequence between GCP364 and GCP372/giantin (Fig. 5B). The 


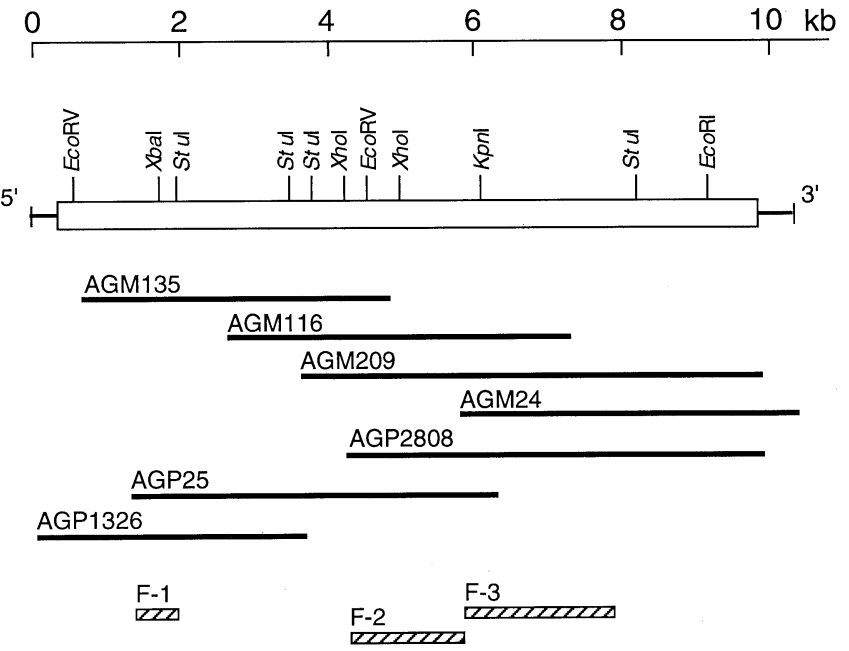

Fig. 2. Restriction map of cDNA clones for the Golgi-antigen obtained from the NRK cDNA library. cDNA clones with AGM numbers were obtained by screening with the autoantibodies as a probe, while clones with AGP numbers were by hybridization with appropriate fragments of the AGM clones. The protein coding region is indicated by a thick open bar. The cDNA fragments F-1, F-2 and F-3 indicated by hatched bars were used for expression of fusion proteins with GST, the products of which were used for immunization.

$\mathrm{NH}_{2}$ - and $\mathrm{COOH}$-terminal non-coil domains also show a high similarity with $62 \%$ and $82 \%$ identity, respectively, and the putative transmembrane domain at the $\mathrm{COOH}$ terminus (Fig. 4) has $95 \%$ identity between the two proteins. In contrast, the internal non-coil segments have a relatively low similarity with $38-45 \%$ identity.

The Identity of GCP364 with the Golgi Autoantigen. Antibodies for GCP364 were raised in rabbits by injecting recombinant fusion proteins derived from the three coding regions F-1, F-2 and F-3 of the GCP364 cDNA (see Fig. 2). The resulting antibodies (antirGCP364) were used for indirect immunofluorescence microscopy and immunoblotting. Double staining of NRK cells with the autoantibodies and the antirGCP364 showed essentially the same profile, demonstrating that both antibodies recognized the same antigen localized at the perinuclear regions (Fig. 6A). Immunoelectron microscopy confirmed that the immunoperoxidase with the anti-GCP364 antibodies specifically stained the Golgi complex (data not shown), as observed with the autoantibodies (Fig. 1A, C). In addition, immunoblot analysis of cell lysates showed that the anti-rGCP364 reacted with an approximately 360$\mathrm{kDa}$ protein in NRK cells and also cross-reacted with that of COS-1 and HepG2 cells (Fig. 6B). The apparent molecular mass of the protein corresponds to that obtained with the autoantibodies (Fig. 1B) and is reasonably consistent with those calculated from the predicted

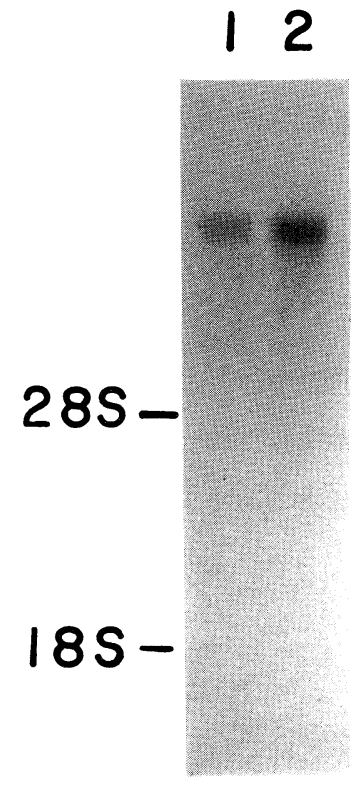

Fig. 3. Northern blot analysis of GCP364 mRNA. Total RNA (10 $\mu \mathrm{g}$ for lane 1$)$ and poly(A) ${ }^{+}$RNA (2.5 $\mu \mathrm{g}$ for lane 2$)$ prepared from NRK cells were denatured and separated by electrophoresis on a $1 \%$ agarose gel. The RNA was blotted onto a membrane and hybridized with ${ }^{32} \mathrm{P}$-labeled fragments prepared from the cDNA clones AGM24 and AGP1326. RNA size markers are $28 \mathrm{~S}$ and $18 \mathrm{~S}$ rRNAs of rat liver.

sequences (364-372 kDa).

The expression plasmid pGCP364/pSG5 encoding the complete GCP364 sequence was constructed and transfected into COS-1 cells. The transfected cells were examined by immunofluorescence and immunoblotting with the anti-rGCP364 antibodies. As shown in Fig. $7 \mathrm{~A}$, strong immunofluorescence was detected at juxtanuclear regions corresponding to the Golgi complex in the transfected cells (panel b). Mock-transfected cells showed a more faint and compact staining profile under the same conditions (panel a). A broader distribution of the immunofluorescence in the transfected cells may reflect an accumulation of the antigen associated with the ER caused by its over-expression (20). The immunoblot analysis showed that the anti-rGCP364 detected an increased level of the antigen in the transfected cells (Fig. $7 \mathrm{~B}$, lane 2), in contrast to that of the endogenous antigen in the control cells (lane 1). Essentially the same results were obtained when the autoantibodies were used for immunofluorescence microscopy and immunoblotting (data not shown).

Taken together, these results indicate that the cDNA constructed encodes the full-length of GCP364 which is the same protein as that recognized by the autoantibodies from the RA patient.

Membrane Interaction of GCP364. GCP364 contains a hydrophobic domain only at the $\mathrm{COOH}$ terminus which could participate in membrane localization. 
MLSRLSSGLANNVLHEL SGDYTGNITMTISSEAEILPOGSAMEINNNSTOKDVLDRLADAEKLVLELLKDIISKQDAQLQQKDEALQEEEKKGAESKTKKIKLHAK 100 AKITSLNKQIEFI KTQGGAASPPEVQAEFISKKHDKSSTEEFMEVEKIKHEIQEKKEKLISNLQAQLDQAQSEQASQLDKSSAEMEDFILMRQKLQEKEELII 200 GALQTQLSQTQAEQAAQKLRVMQRKLFEHEFALLGRAQVDLLOKELTSAEQRNQDLSQQLQLLEAEHSTLRNTMEAERQESKILMEKVEUEMAERKEEL 300 YQLQGQLERAGQAQAET ENQYGTLQQRHETEMEFKTACISLLQKNEQEL_QSACDALKKEFNSKL_LEQQEQAAKSAQALQQLEDELLQKSKEISQFVNKPN 400 LEKHETSSQTSLPDVYNEGVQAVMEESVASLQKRVLEL_ENEKGALLLSSLELLEFILRAENEKLCSRITLLEAQNRAGEADGMVCEVSTAGIALINRRSDST 500 EESGQDVLENTFSQKHKELSVILVEMKEAQEEIAFLKSQLQGKRPEGDYEVLDRKEVQMMESEGLPSVTARDVLCAPRDKNSVPAVEGEQAGMRDQHGTL 600

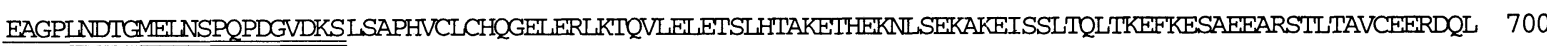
LYRVKEILDVLGEIRAQVRETETSLAEAEKQRGLDYESQRAQHNLLTEQIHSLSIEAKSKDVKIETLQREIDGVVLQFSEQGTQIKSLQSQLQTKESEVLE 800

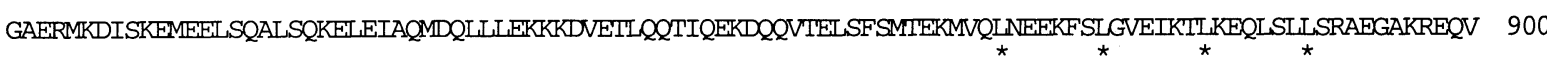
EDSGAESSPKHGPHESSAEEPVCKEALQQEU EWLRKESEQRKRKLQAALISRKELLQKVSKLFEET_AKVREESTKDSLRESEKREI FEDSKNKDDPEKYG 1000 TSEWREI_EVSLRLTISEKEVEI_EGIRRDLKEIKAAAEEELQALVQRMTQDLQNKTKQIDLLQEEITENQATIQKFITGIMDAGDGDSAVKETSVSSPPRAG 1100

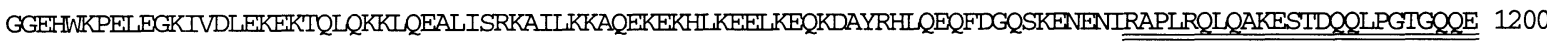
PIHGSEGLSLEGTEPASESDLHAAQPSHPGETATLQATVSVAQIQDQLKEIEVEKEEILELKISSTTSELTKKSEEVLLLQEQINEQGLEIQNLKAASHEA 1300 KAHTEQLKQELESSQLKIADLFHLKTLQPEILETLQKHVGQKEFEVSYLVGLLGEKEQILTTVQTEMEFQERLIKALHTQLEMQAKEHEERLKQVQVEICE 1400 LKKQPKET_EFESKAKQQLQRKLQAALISRKEALKENKSLQEQLSSARDAVEHLTKSLADVESQVSVQNQEKDALLGKLALLQEERDKLIVEMDKSLUENQ 1500 SLGGSCESLKL_ALGGLTEDKEKLMKEIESVRCSKIAESTEWQEKHKEL_KEYEVLLQSYENVSNEAERIQHVVESVRQEKQEVYAKLRSAESDKREREKQ 1600

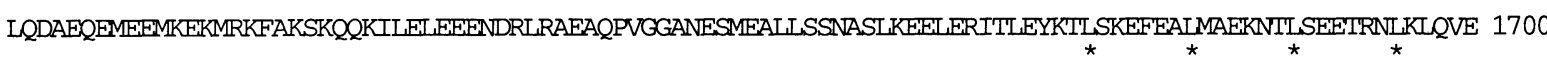
AQELKQASLETTEKSDEPKDVIEEVIEAVVGKSQEQDSLSENAKLEEAEATLLANSAKPGVSETFSSHDDINNYLQQLDQLKGRIAET_EMEKQKDRELSQ 1800 TLENEKKNALLTQISAKDSELKLLEFEVAKMNMLNQQIQEFISTRVTKLKETAEFEKDDLFERLMNQLAEINGSIGNYYQDVIDAQIKNEQLESEMQNLKRC 1900

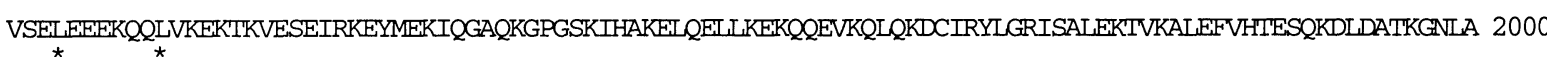
QAVEHHKKAQAEISSSFKILDDTQSEAARVLADNLKLKKELQSNKESIKSQIKQKDEDLLRRLEQAEEKKHRKEKKNMQEEKLDALHREKAHVEDILAEIQV 2100 SLTRKDKDMKELLQSLDSTLAQLAAFTKSMSSLQDDRDRVIDEAKKWEQRFGDAIQTKEFEVVRLKEENCTALKDQLRQMTIHMEFIKITVSRLEHDKEIW 2200 ESKAQTEL_HQQKAYDKLQEFNKEIMSLLFEAGLLYHDSKNEITKLESEL_KSLKDDSTDLKNSLEKCREHENNLEGITKQQEADIQNCKFNCEQLETDLT 2300 ASREITTRLHDETNVKEQKIISLLSGKKEFAIQVATAEIHQQHSKEIKEI_ENLISQEEEEENLTTEFEENKRAVEKTNQLTEALETIKKESLEQKAQLDSFVK 2400 SMSSLQDDRDRTVSDYRQLEERHLSVILEKDELIQDAAAENNKL_KEEIRGLRGHMDLNSENAKLDAELIQYRRDLNEVITIKDSQQRQLEAQLQQRNKE 2500 LRNECVKLFEGRLKGSEAEKQSLQMSLDALQEENQGLSKEIKSFKEQLTALHEEGALAVYHAQLRVREFEVQKLTAALSSSQKRTVDLQEELVCVQKEASK 2600 KVSEIEDKLKREI KHLLHHNAGIMRNETETAEERVAEI ARDLVEMEQKLLTVIKENKDLTAQIQAFGKSMSSLQDSRDHATEEISSDLKKKYDASLKEI_AQL 2700 KGRQDLGRESDVLSQAAFPLTTSENISSRLEKKLNQQLISKDEQLLHLSSEIESSHNQVQSFTKAMTSLQNERDHLWNELEKFRKSEFGKQRSAAPSAASS 2800

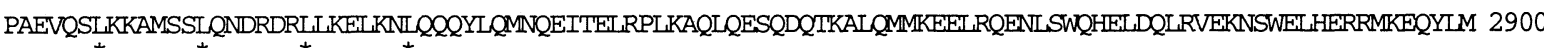
AISDKDQQLGHLQNLIREIRSSSQTQILPTQYQRQASSGTSAALDGSQNLVYEIDCLRTQLNDSLKEIHQKEILRIQQLNSKFSQLUEFKNILSTQLRDAN 3000 QSLRDSQHHYSNLFNHCAILERQVQQLQATGPLNADVAPGAPQEKDGIHIKTEIETTGEEQPSFSEVQQQLCNIKHDLSELKKLLEFERDQRLTAENALS 3100 LAKEQIRRLEHSEWESARTPIIGACGSOEOVLLMDLPGSSCRRTRSSAGWKRVLRSLCRSRTRVPILAATYFL MITHVLVLCFITHI

Fig. 4. Deduced amino acid sequence of the Golgi-antigen GCP364. Amino acid residues are shown in the single-letter code. Leucine residues in the coiled-coil leucine zipper motif are indicated by asterisks. $\mathrm{NH}_{2}$ - and $\mathrm{COOH}$-terminal non-coil domains are single-underlined. Three major non-coil domains interrupting the coiled-coil structure are double-underlined. Boldfaced letters at the $\mathrm{COOH}$-terminal sequence indicate a putative membrane-anchoring domain. The nucleotide sequence of GCP364 has been deposited in the DDBJ/EMBL/GenBank Data Libraries under the accession number D25543. 


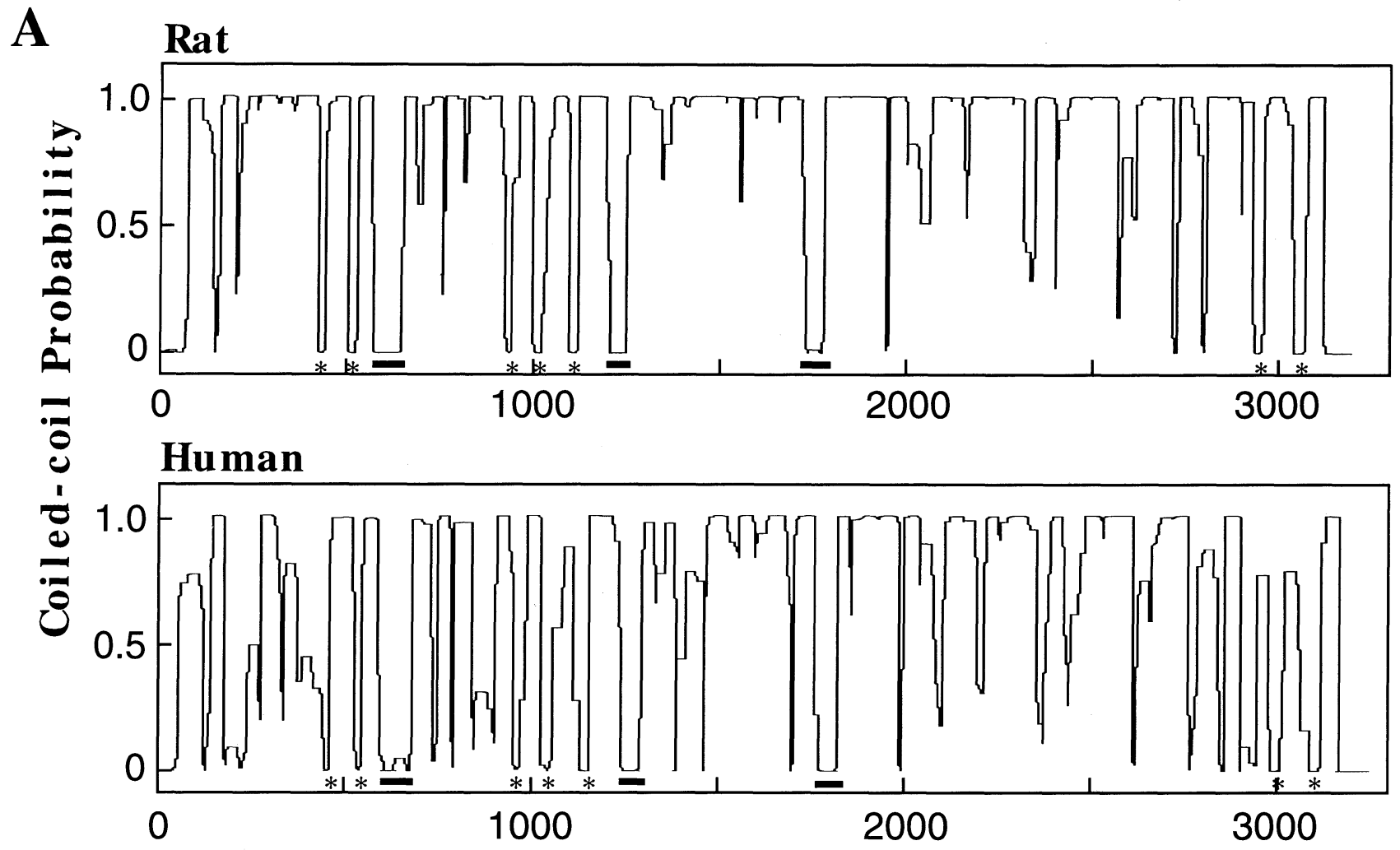

Amino Acid Residue Number

B

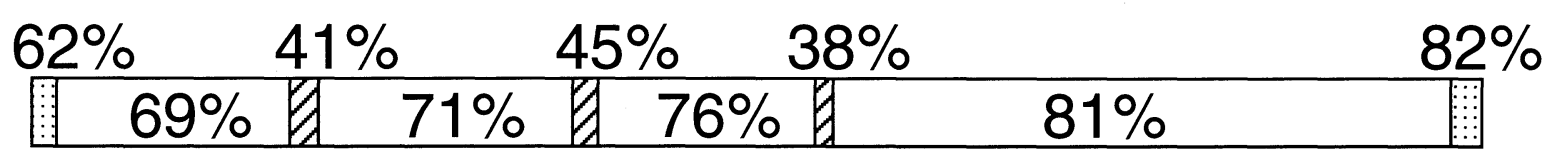

Fig. 5. Similarity of the primary and secondary structures between rat GCP364 and human giantin. (A) Coiled-coil probabilities of GCP364 and giantin. The probability profiles were made from data generated by COILS (ver. 2.1) algorithm. The MTDIK matrix and a window size of 28 residues were used. Three major (more than 50 residues) and seven minor (less than 50 residues) non-coil domains are indicated by thick bars and asterisks, respectively. (B) Domain-dependent similarities in the primary structure of the two proteins. The similarities are expressed as \% identity in the sequences of individual domains which were determined by the coiled-coil probability shown in (A); four overall coiled-coil domains (open boxes), three major internal non-coil domains (hatched boxes) and the $\mathrm{NH}_{2}$ - and $\mathrm{COOH}$-terminal non-coil domains (dotted boxes).

We examined an interaction of GCP364 with membranes. When a PNS fraction of NRK cells in the homogenizing buffer was separated by centrifugation into membranes and cytosol, GCP364 was completely sedimented with the membranes (Fig. 8, lanes 1 and 2). No GCP364 was released from the membranes by treatment with $1 \mathrm{M} \mathrm{NaCl}$. The membranes were then treated with either $0.1 \mathrm{M}$ sodium carbonate $(\mathrm{pH} \mathrm{11)}, 1 \%$ Triton $\mathrm{X}-100$ or $1 \%$ sodium deoxycholate. GCP364 was not extracted from the membranes by the sodium carbonate treatment (Fig. 8, lanes 3 and 4), and partially extracted with Triton X-100 (lanes 5 and 6). The complete extraction of the protein was carried out by the deoxycholate treatment (lanes 7 and 8 ). The results indicate that
GCP364 is an integral membrane protein, possibly anchoring to the membranes by the $\mathrm{COOH}$-terminal hydrophobic domain.

No Involvement of GCP364 in the Formation of Coated Vesicles. The formation of COP I-coated vesicles is characterized by assembly of ARF and coatomer from the cytosol to the Golgi membrane $(31,33)$. However, little information is available for membrane proteins involved in the interaction with these coat proteins. We examined a possible involvement of GCP364 in the formation of the coated vesicles, which were accumulated in vitro by incubating the Golgi membranes in the presence of GTPrS (7). Localization of GCP364 was detected by immunogold labeling and compared 
A
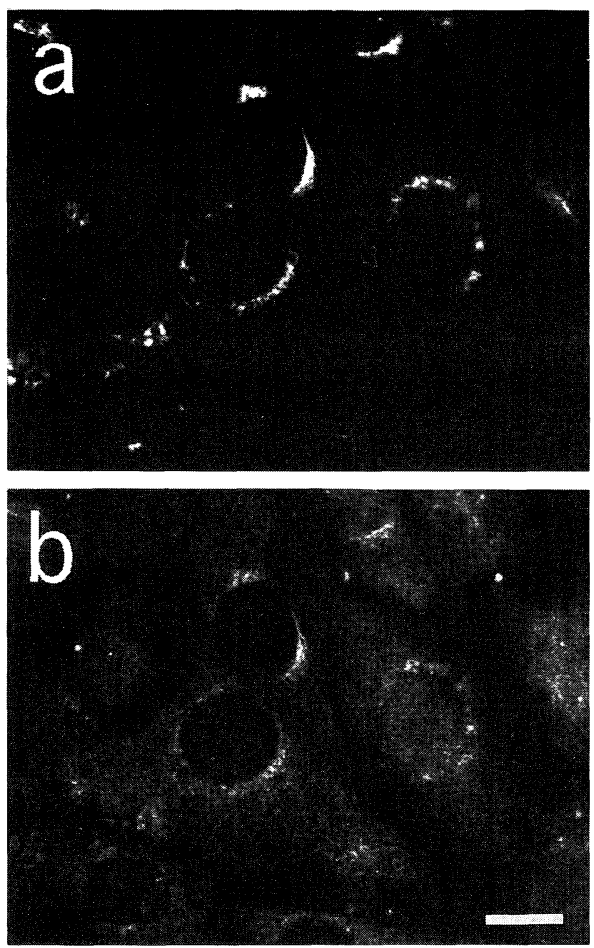

B

$\begin{array}{llll}k D a & 1 & 2 & 3\end{array}$

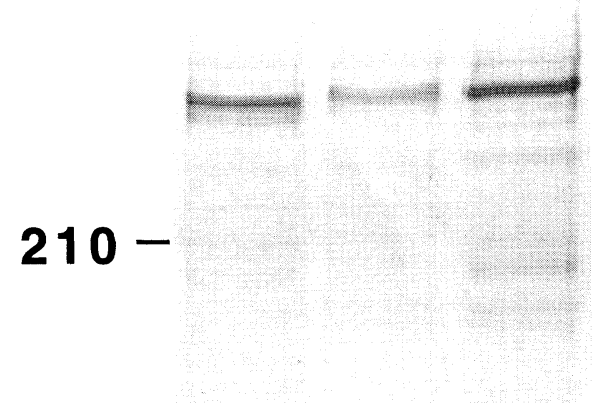

105

Fig. 6. Reactivity of rabbit anti-recombinant GCP364 antibodies. (A) Double immunofluorescence staining of NRK cells. Fixed cells were incubated with rabbit anti-rGCP364 antibodies (a) and human autoantibodies (b), followed by incubation with rhodamine-conjugated anti-rabbit IgG and Cy2-conjugated anti-human IgG. Scale bar, $10 \mu \mathrm{m}$. (B) Immunoblot analysis with the anti-rGCP364 antibodies. Cell lysates (30 $\mu \mathrm{g}$ /lane) prepared from NRK (lane 1), COS-1 (lane 2) and HepG2 cells (lane 3) were separated by SDS-PAGE (5\% gel), and subjected to immunoblotting with the anti-rGCP364 antibodies. Molecular mass markers used are the same as those in Fig. 1.

with that of $\beta$-COP, a subunit of the coatomer. The coated vesicles were labeled with immunogold particles for $\beta$-COP (Fig. 9B), but not significantly labeled with those for GCP364, which were detected on other membrane components (Fig. 9A). These observations suggest that GCP364 is not directly involved in the budding and formation of the Golgi-derived coated vesicles.

Effect of Anti-rGCP364 Antibodies on the Golgi Structure. A possible function of GCP364 was examined by incubation of cells with anti-rGCP364 antibodies after cells were perforated (39). The perinuclear localization and characteristic morphology of the Golgi complex were found to be maintained in the perforated cells (Fig. 10A) and not so significantly altered even after incubation of the cells with non-immune serum at $37^{\circ} \mathrm{C}$ for $1 \mathrm{~h}$ (Fig. 10B). In contrast, when cells were incubated with anti-rGCP364 antiserum, the Golgi complex marked with ManII was disassembled into small fragment-like structures which were dispersed in the cytoplasm (Fig. 10C). These changes of the Golgi structure were quite similar with those in cells treated with the microtubule-depolymerizing drug nocodazole (Fig. 10D). However, the network of microtubules was still almost normally maintained in the anti-rGCP364-treated cells (Fig. 10E), in contrast to the complete depolymerization of microtubules in the nocodazole-treated cells (Fig. 10F). These results suggest that GCP364 may be involved in the maintenance of the characteristic Golgi structure.

\section{DISCUSSION}

Autoantibodies which recognize antigens in the Golgi complex are occasionally found in sera from patients with autoimmune diseases including RA $(17,37,41)$, Sjögren's syndrome (7) and systemic lupus erythematosus $(8,9)$. Although the clinical relevance of the production of such autoantibodies is uncertain, these antibodies could provide useful tools for structural analysis of the Golgi complex. In addition to production of monoclonal and polyclonal antibodies to Golgi membranes $(19,27)$, screening of clinical serum samples for the 
A
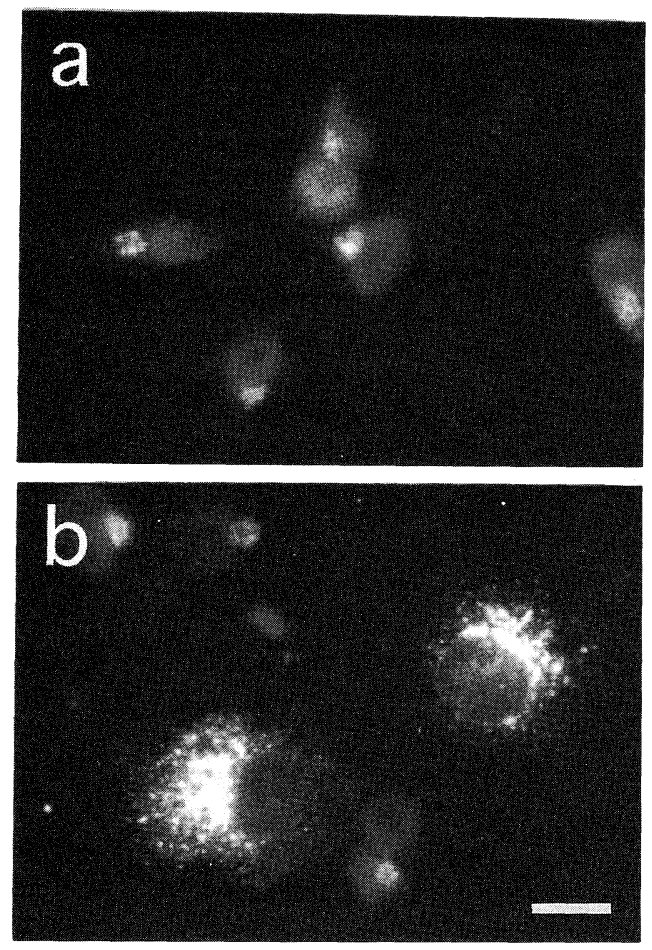

B

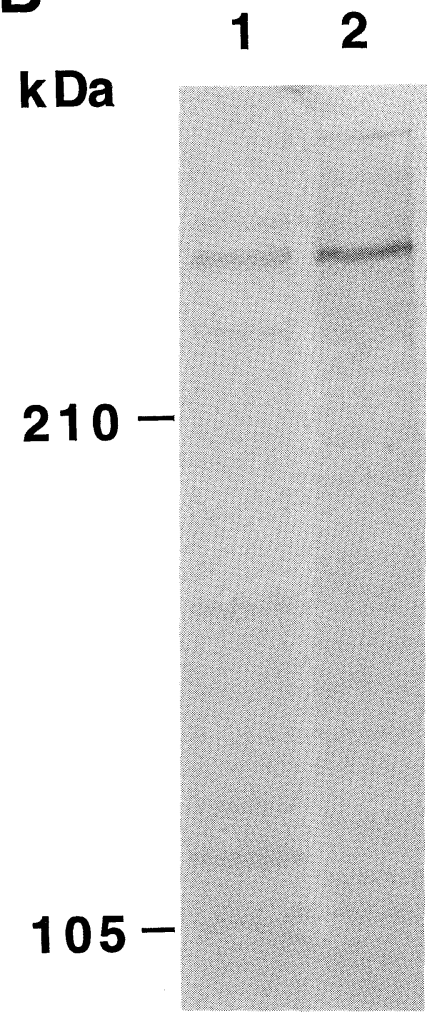

Fig. 7. Analysis of GCP364 expressed in COS-1 cells. COS-1 cells were transfected with pSG5 expression vector alone or pGCP364/pSG5 and cultured for 2 days before use. (A) Immunofluorescence staining of the mock-transfected (a) and transfected cells (b) with anti-rGCP364 antibodies. Scale bar, $10 \mu \mathrm{m}$. (B) Immunoblot analysis of the mock-transfected (lane 1) or transfected cells (lane 2). Cell lysates (30 $\mu$ g) were separated by SDS-PAGE (5\% gel) and subjected to immunoblotting wiith the anti-rGCP364 antibodies.

anti-Golgi autoantibodies is a convenient way to identify proteins associated with the Golgi complex (7-9, 17, $37,41)$. It is commonly observed that Golgi antigens so far identified are cytoplasmically disposed peripheral and integral membrane proteins.

In the present study we have isolated cDNA clones for a Golgi-associated protein recognized by autoantibodies from a patient with RA, for which the NRK cDNA library was used since the NRK cells were most intensely stained with the autoantibodies-coupled immunofluorescence. Although we could not obtain a single cDNA clone which should cover all the coding region, overlapping inserts of the obtained cDNA clones demonstrated that the combined sequence has $11 \mathrm{kbp}$ of DNA, which encodes a 3,187-residue protein with a calculated mass of $364 \mathrm{kDa}$ (GCP364). The fact that this is the complete cDNA for the antigen recognized by the auto-antibodies was confirmed by the following findings. 1) The presence of the mRNA with the same size (11 kb) was identified by the Northern blotting. 2) AntirGCP364 antibodies recognized the same antigen as that detected by the autoantibodies. 3) The product ex- pressed by transfection with the cDNA was recognized by the autoantibodies as well as the anti-rGCP364 and had the same molecular mass as that of the endogenous antigen.

Hydropathy plot analysis of the predicted sequence showed that GCP364 has no signal sequence at the NH2 terminus but a single hydrophobic domain at the $\mathrm{COOH}$ terminus, indicating that the protein is cytoplasmically disposed and anchored to the Golgi membrane by the $\mathrm{COOH}$-terminal hydrophobic domain. No extraction of GCP364 from the membrane with sodium carbonate treatment confirmed that it is an integral membrane protein (10). The membrane topology of GCP364 with extension to the cytoplasm was further supported by the fact that when isolated intact Golgi membranes were treated with trypsin/chymotrypsin, the protein was no longer detected in the membranes while the lumenal membrane protein ManII remained almost intact (Fujiwara, T. and Ikehara, Y.; unpublished results).

The nucleotide and amino acid sequences of GCP364 have $78 \%$ and $75 \%$ identity, respectively, with those of human GCP372/giantin. Giantin was initially identified 


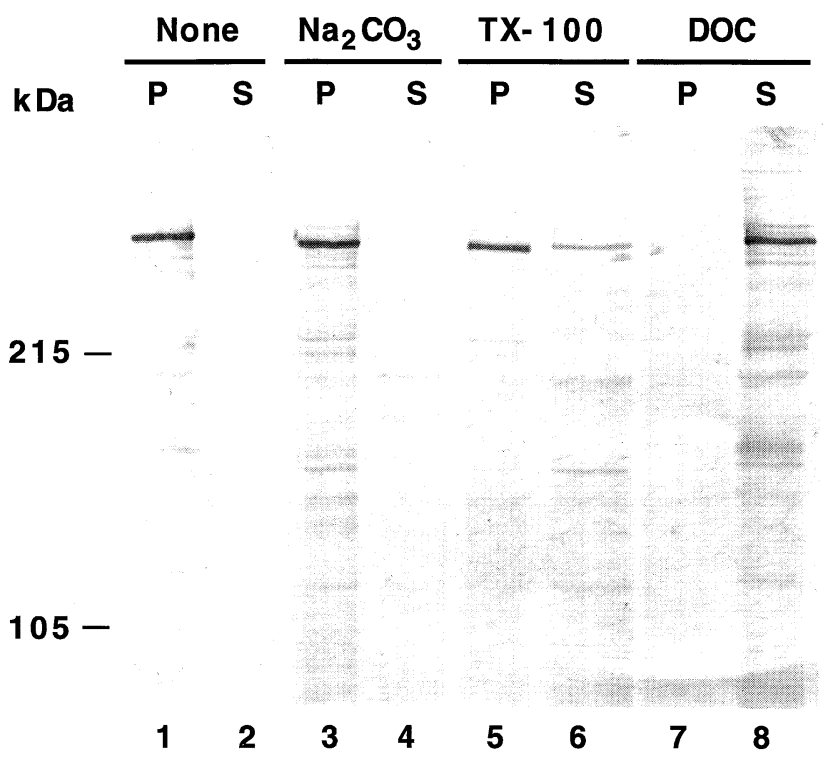

Fig. 8. Analysis of membrane interaction of GCP364. A membrane fraction prepared from the PNS of NRK cells was treated with either buffer alone (lanes 1 and 2), $0.1 \mathrm{M} \mathrm{Na}_{2} \mathrm{CO}_{3}$ (lanes 3 and 4), $1 \%$ Triton $\mathrm{X}-100$ (lanes 5 and 6 ) or 1\% sodium deoxycholate (lanes 7 and 8 ), and the treated samples were separated by centrifugation into pellets $(P)$ and supernatants (S). All the samples (10 $\mu \mathrm{g}$ protein each) were separated by SDS-PAGE $(5 \%$ gel) and subjected to immunoblotting with the anti-rGCP364 antibodies.

as a $\sim 400-\mathrm{kDa}$ Golgi-associated protein which was recognized by a monoclonal antibody directed to Caco-2 Golgi membranes (19) and also by autoantibodies from a patient with RA (37). The primary structure of giantin $(376 \mathrm{kDa})$ was predicted by cloning and sequencing of its cDNA (37). GCP372 we independently identified with autoantibodies from a patient with RA is an isoform of giantin, lacking the $\mathrm{NH}_{2}$-terminal 34 amino acid residues (41). The complete identity in the other sequence indicates that the two proteins are produced by alternative splicing of transcripts from the same gene. Since we have isolated both the giantin and GCP372 cDNA clones from the same HepG2 cDNA library, it is likely that the two proteins are actually expressed in cells. Rat GCP364 has a similar $\mathrm{NH}_{2}$-terminal extension as that of giantin, indicating that GCP364 is a homolog of giantin in the strict sense, although we cannot rule out a possible existence in rat of another form corresponding to GCP372. The difference in molecular mass between rat GCP364 and human GCP372/giantin is due to one major and two minor deletions which are found between positions 220 and 580 from the $\mathrm{NH}_{2}$ terminus.

The almost entire sequences of GCP364 and GCP372 /giantin are occupied by coiled-coil structures, which are divided into four major domains by three relatively long gaps interrupting the coiled-coil (Fig. 5). The se-
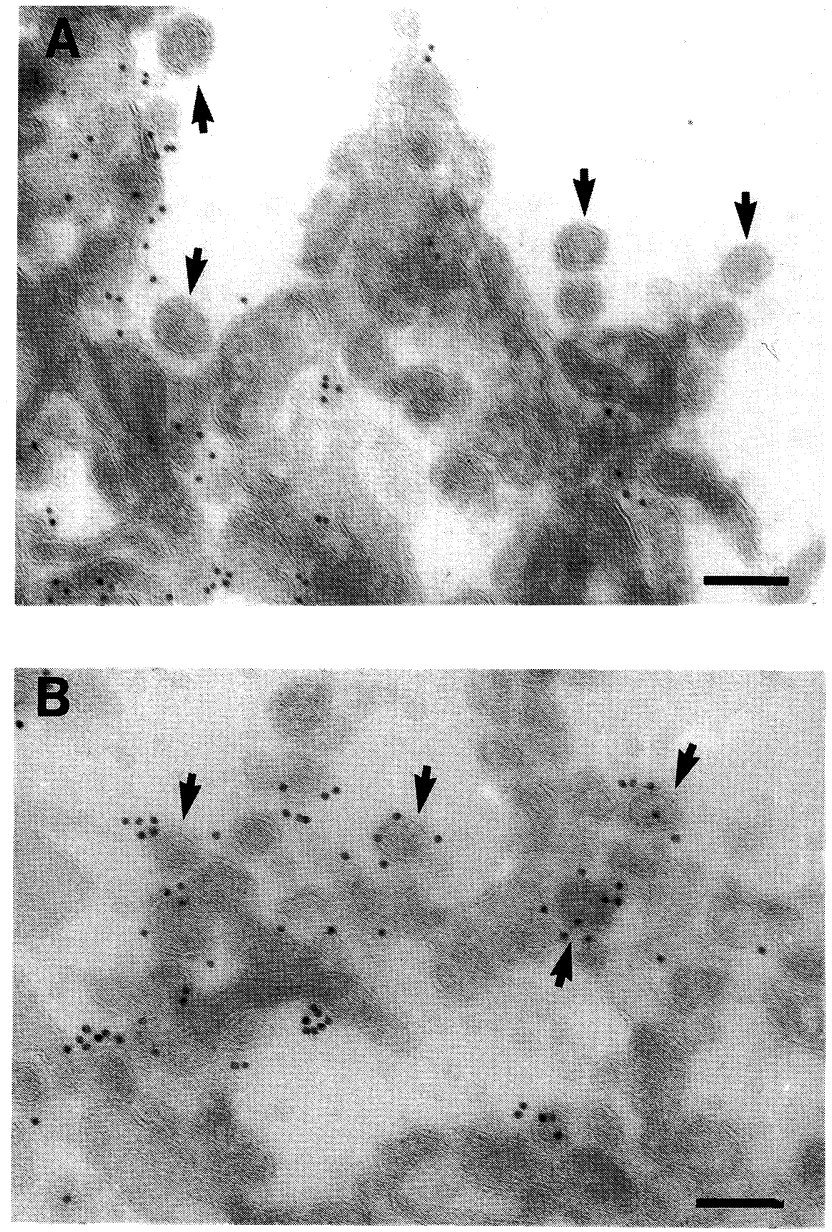

Fig. 9. In vitro accumulation of Golgi-derived coated vesicles and immunogold labeling. A Golgi-rich fraction prepared from rat liver ws incubated with $20 \mu \mathrm{M}$ GTP $\gamma \mathrm{S}$ under the conditions described in the Methods. The samples were pelleted, fixed and cryosectioned. The sections were incubated with anti-rGCP364 (A) or anti- $\beta$-COP (B) antibodies, followed by incubation with Protein A-conjugated gold particles. Arrows indicate coated vesicles. Scale bar, $0.1 \mu \mathrm{m}$.

quence similarity of the rat and human proteins is much higher in the coiled-coil domains (69-81\%) than in the gaps $(38-41 \%)$, suggesting that these coiled-coil domains play an important role in structure and function of the proteins. The evidence that a long charge-rich $\alpha$ helical domain is commonly found in autoantigens (5) suggests that the conserved coiled-coil domains serve as antigenic epitopes for producing the autoantibodies in patients with autoimmune diseases. In fact, the autoantibodies cross-react well with the corresponding antigens in cells from various species including mammalian and avian (41).

The coiled-coil domain is now considered, in addition to as a DNA binding motif, as a mediator of dior oligomerization by its hydrophobic interaction, as 

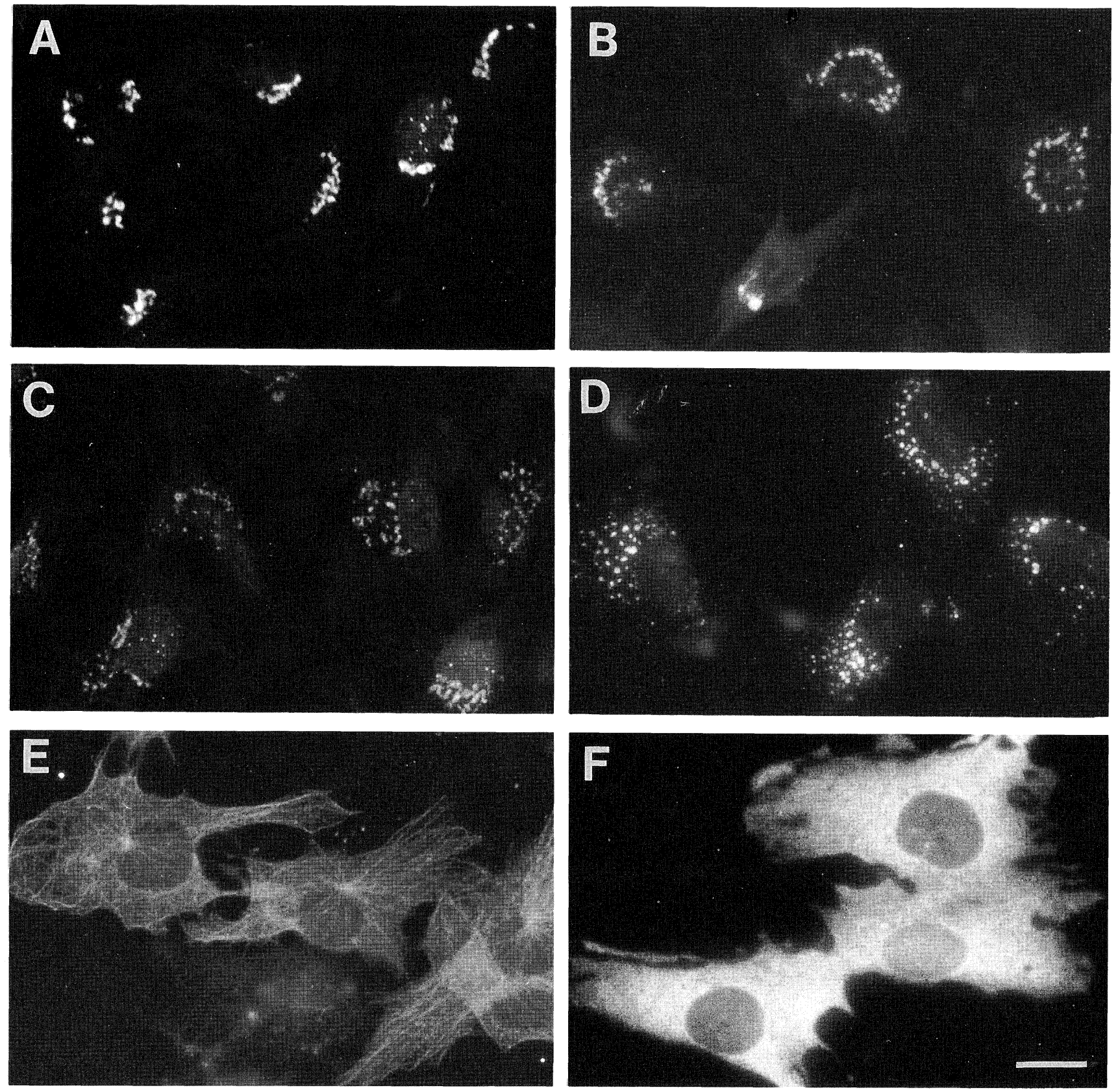

Fig. 10. Morphological change of the Golgi complex in cells incubated with anti-GCP364 antibodies. Perforated NRK cells (A-C and E) were immediately fixed (A) or incubated at $37^{\circ} \mathrm{C}$ for $1 \mathrm{~h}$ with non-immune serum (B) or anti-rGCP364 serum (C and E) in medium A containing cytosol and the ATP-regenerating system. Intact cells (D and F) were incubated at $37^{\circ} \mathrm{C}$ for $1 \mathrm{~h}$ in the Dulbecco's minimum essential medium containing $50 \mu \mathrm{M}$ nocodazole. The cells were washed, fixed and stained either with monoclonal anti-Man II antibody and rhodamine-conjugated antimouse IgG (A-D) or with goat anti- $\alpha$-tubulin antibody and Cy2-conjugated anti-goat IgG (E and F). Scale bar, $10 \mu \mathrm{m}$.

shown in HIV envelope proteins (42) and influenza hemagglutinin (3). It was also reported that coiled-coil domains are involved in trimerization of cartilage matrix protein subunits which is stabilized by intermolecular disulfide bonding of cysteine residues in the coiled-coil domains (15). As it was suggested that giantin exists as a di- sulfide-linked homodimer (19), the coiled-coil domains of GCP364 may play a role in the formation of homoor hetero-oligomers. Other Golgi-associated peripheral proteins such as golgin-245/p230 $(7,9)$, golgin-95 and golgin-160 (8), p115 (36) and GM130 (26) also have long coiled-coil domains. These proteins possibly exist as 
homo-oligomers and/or interact with other proteins by their coiled-coil domains, as demonstrated by Nakamura et al. (26). On the other hand, the gap domains between the coiled-coils could contribute to protein structure and function by creating a fixed bend or a flexible hinge (28). Although the amino acid sequences in the gaps show low similarities, the numbers and positions of the gaps are well conserved in the rat GCP364 and human GCP372/giantin.

The biological function of GCP364 remains to be clarified. The preferential localization of GCP364 and GCP372 (41) on rims of the Golgi cisternae suggests the possibility that the proteins are involved in the budding and formation of transport vesicles. This possibility, however, is not supported by our in vitro experiments demonstrating that GCP364 is not detected on the coated vesicles accumulated by incubation with GTP $\gamma$ S. Recently it has been reported that $\beta$-spectrin (2) and ankyrin (4) homologs are associated with the Golgi complex and may act to organize micro-domains within the Golgi membrane by linking them to cytoskeletons. In addition, since microtubule-depolymerizing agents such as nocodazole and colchicine cause fragmentation and dispersion of the Golgi complex, interaction of the Golgi complex with microtubule network is important to maintain the appropriate Golgi structure (18). Under the conditions which stabilize the microtubule and actin filament networks, giantin (19) and GCP364 (not shown) are not extracted with Triton X-100 and keep the association with an apparently preserved Golgi structure, in contrast to easy extraction of the lumenal membrane proteins galactosyl transferase and ManII. Thus, these observations suggest that the giantin family proteins may function as a scaffold protein of the Golgi complex, which stacks the Golgi cisternae and stabilizes the organelle structure. This may be supported by the present finding that treatment of cells with antirGCP364 antibodies causes disruption of the Golgi complex. Further studies are required to obtain more direct evidence for the interaction of GCP364 with the cytoskeletons. It is also of interest to know whether GCP364 interacts with other Golgi-associated proteins having the long coiled-coil domains.

Acknowledgments. This work was supported in part by grants from the Ministry of Education, Science, Sports and Culture of Japan, the Japan Science and Technology Corporation, the Japan Private School Promotion Foundation, the Naito Foundation, and the Central Research Institute of Fukuoka University. We wish to thank Dr. A. Lupas (Max-Planck Institute, Germany) for useful information on the analysis of coiled-coil structures and Dr. K. Moreman (University of Georgia, U.S.A.) for supplying us with rabbit anti-rat $\alpha$-mannosidase II antibodies. We also thank C. Hashimoto and A. Yano for technical assistance.

\section{REFERENCES}

1. Balch, W.E., Dunphy, W.G., Braell, W.A., and Rothman, J.E. 1984. Reconstitution of the transport of protein between successive compartments of the Golgi measured by the coupled incorporation of N-acetylglucosamine. Cell, 39: 405-416.

2. Beck, K.A., Buchanan, J.A., Malhotra, V., and Nelson, J. 1994. Golgi spectrin: Identification of an erythroid $\beta$-spectrin homolog associated with the Golgi complex. J. Cell Biol., 127: 707-723.

3. Bullough, P.A., Hughson, F.M., Skehel, J.J., and Wiley, D.C. 1994. Structure of influenza haemagglutinin at the $\mathrm{pH}$ of membrane fusion. Nature, 371: 37-43.

4. Deverajan, P., Stabach, P.R., Mann, A.S., Ardito, T., Kashgarian, M., and Morrow, J.S. 1996. Identification of a small cytoplasmic ankyrin (AnkG119) in the kidney and muscle that binds $\beta \mathrm{I} \Sigma^{*}$ spectrin and associated with the Golgi apparatus. J. Cell Biol., 133: 819-830.

5. Dohlman, J.G., Lupas, A., and Carson, M. 1993. Long charge-rich alpha-helices in systemic autoantigens. Biochem. Biophys. Res. Commun., 195: 686-696.

6. Donaldson, J.G., Finazzi, D., and Klausner, R.D. 1992. Brefeldin A inhibits Golgi membrane-catalysed exchange of guanine nucleotide bound to ARF. Nature, 360: 350-352.

7. Erlich, R., Gleeson, P.A., CAmpbell, P., Dietzsch, E., and Tон, B.-H. 1996. Molecular characterization of trans-Golgi p230: A human peripheral membrane protein encoded by a gene on chromosome 6p12-22 contains extensive coiled-coil $\alpha$-helical domains and a granin motif. J. Biol. Chem., 271: 8328-9337.

8. Fritzler, M.J., Harmel, J.C., OChs, R.L., and Chan, E.K.L. 1993. Molecular characterization of two human autoantigens: Unique cDNAs encoding $95-$ and $160-\mathrm{kD}$ proteins of a putative family in the Golgi complex. J. Exp. Med., 178: 49-62.

9. Fritzler, M.J., Lung, C.-C., Hamel, J.C., Griffith, K.J., and CHAN, E.K. 1995. Molecular characterization of golgin245 , a novel Golgi complex protein containing a granin signature. J. Biol. Chem., 270: 31262-31268.

10. Fujiki, Y., Hubbard, A.L., Fowler, S., and Lazarow, P.W. 1982. Isolation of intracellular membranes by means of sodium carbonate treatment: Application to endoplasmic reticulum. J. Cell Biol., 93: 97-102.

11. Fujiwara, T., Oda, K., Yokota, S., Takatsuki, A., and IKeharA, Y. 1988. Brefeldin A causes disassembly of the Golgi complex and accumulation of secretory proteins in the endoplasmic reticulum. J. Biol. Chem., 263: 18545-18552.

12. Fujiwara, T., Oda, K., and Ikehara, Y. 1989. Dynamic distribution of the Golgi marker thiamine pyrophosphatse is modulated by brefeldin A in rat hepatoma cells. Cell Struct. Funct., 14: 605-616.

13. Funaki, T., Fujiwara, T., Hong, H.-S., Misumi, Y., NiSHIOKA, M., and IKEHARA, Y. 1996. Identification and characterization of a $230-\mathrm{kDa}$ Golgi-associated protein recognized by autoantibodies from a patient with HBV hepatitis. Cell Struct. Funct., 21: 63-72.

14. Haruta, T., Takami, N., Ohmura, M., Misumi, Y., and IKEHARA, Y. 1997. $\mathrm{Ca}^{2+}$-dependent interaction of the growthassociated protein GAP-43 with the synaptic core complex. Biochem. J., 325: 455-463.

15. Haudenschild, D.R., Tondravi, M.M., Hofer, U., Chen, Q., and GoETINCK, P.F. 1995. The role of coiled-coil $\alpha$-helices and disulfide bonds in the assembly and stabilization of cartilage matrix protein subunits. J. Biol. Chem., 270: 23150-23154.

16. Helms, J.B. and Rothman, J.E. 1992. Inhibition by brefeldin 
A of Golgi membrane enzyme that catalyses exchange of guanine nucleotide bound to ARF. Nature, 360: 352-354.

17. Hong, H.-S., Morshed, S.A., Tanaka, S., Fujiwara, T., IKEHARA, Y., and NishioKA, M. 1992. Anti-Golgi antibody in rheumatoid arthritis patients recognizes a novel antigen of 79 $\mathrm{kDa}$ (doublet) by Western blot. Scand. J. Immunol., 36: 785792.

18. KREIS, T.E. 1990. Role of microtubules in the organization of the Golgi complex. Cell. Motil. Cytoskeleton, 15: 679-693.

19. Linstedt, A.D. and Hauri, H.-P. 1993. Giantin, a novel conserved Golgi membrane protein containing a cytoplasmic domain of at least $350 \mathrm{kDa}$. Mol. Biol. Cell, 4: 679-693.

20. Linstedt, A.D., Foguet, M., Renz, M., Seelig, H.P., Glick, B.S., and HAURI, H.-P. 1995. A C-terminally-anchored Golgi protein is inserted into the endoplasmic reticulum and then transported to the Golgi apparatus. Proc. Natl. Acad. Sci. USA, 92: 5102-5105.

21. LippincotT-Schwartz, J., Yuan, L.C., Bonifacino, J.S., and KLAUSNER, R.D. 1989. Rapid redistribution of Golgi proteins into the ER in cells treated with brefeldin A: Evidence for membrane cycling from Golgi to ER. Cell, 56: 801-813.

22. Lupas, A., van Dyke, M., and Stock, J. 1991. Predicting coiled coil from protein sequences. Science, 252: 1162-1164.

23. Misumi, Y., Misumi, Y., Miki, K., Takatsuki, A., Tamura, G., and IkeHaRA, Y. 1986. Novel blockade by brefeldin A of intracellular transport of secretory proteins in cultured rat hepatocytes. J. Biol. Chem., 261: 11398-11403.

24. Misumi, Y., Sohda, M., OhKubo, K., Takami, N., Oda, K., and IKEHARA, Y. 1990. Molecular cloning and sequencing of the cDNA of rat $\alpha_{1}$-protease inhibitor and its expression in COS-1 cells. J. Biochem., 108: 230-234.

25. Misumi, Y., Oda, K., Fujiwara, T., Takami, N., Tashiro, K., and IKeHARA, Y. 1991. Functional expression of furin demonstrating its intracellular localization and endoprotease activity for processing of proalbumin and complement pro-C3. J. Biol. Chem., 266: 16954-16959.

26. Nakamura, N., Rabouille, C., Watson, R., Nilssen, T., Hui, N., Slusarewicz, P., Kreis, T.E., and Warren, G. 1995. Characterization of a cis-Golgi matrix protein GM130. J. Cell Biol., 131: 1715-1726.

27. Narula, N., McMorrow, I., Plopper, G., Doherty, J., Matlin, K.S., Burke, B., and Stow, J.L. 1992. Identification of a $200-\mathrm{kD}$, brefeldin A-sensitive protein on Golgi membrane. J. Cell Biol., 117: 27-38.

28. OAS, T.G. and EnDow, S.A. 1994. Springs and hinges: Dynamic coiled coils and discontinuities. Trends Biochem. Sci., 19: $51-54$.

29. Oda, K. and IKehaRA, Y. 1981. Inhibitory effect of colchicine on translocation of alkaline phosphatase to the plasma membrane concomitant to its induction in rat liver. Biochim. Biophys. Acta, 640: 398-408.
30. Ogata, S., Misumi, Y., and Ikehara, Y. 1989. Primary structure of rat liver dipeptidyl peptidase IV deduced from its cDNA and identification of the $\mathrm{NH}_{2}$-terminal signal sequence as the membrane-anchoring domain. J. Biol. Chem., 264: 3596-3601.

31. OrCi, L., Palmer, D.J., Amherdt, M., and Rothman, J.E. 1993. Coated vesicle assembly in the Golgi requires only coatomer and ARF proteins from the cytosol. Nature, 364: 732-734.

32. Rios, R.M., Tassin, A.-M., Celati, C., Antony, C., Boissier, M.-C., HomberG, J.-C., and Bornens, M. 1994. A peripheral protein associated with the cis-Golgi network redistributes in the intermediate compartment upon brefeldin A treatment. J. Cell Biol., 125: 997-1013.

33. Rothman, J.E. and Orci, L. 1992. Molecular dissection of the secretory pathway. Nature, 335: 409-415.

34. Rothman, J.E. 1994. Mechanisms of intracellular protein transport. Nature, 372: 55-63.

35. Sanger, F., Nicklen, S., and Coulson, A.R. 1977. DNA sequencing with chain-terminating inhibitors. Proc. Natl. Acad. Sci. USA, 74: 5463-5467.

36. Sapperstein, S.T., Walter, D.M., Grosvenor, A.R., HEUSER, J.E., and WATERS, G. 1995. p115 is a general vesicular transport factor related to the yeast endoplasmic reticulum to Golgi transport factor Usolp. Proc. Natl. Acad. Sci. USA, 92: 522-526.

37. Seelig, H.P., Schranz, P., Schroter, H., Wiemann, C., and RenZ, M. 1994. Macrogolgin: A new 376 kD Golgi complex outer membrane protein as target of antibodies in patients with rheumatic diseases and HIV infections. J. Autoimmun., 7: 6791.

38. Seguchi, T., Goto, Y., Ono, M., Fujiwara, T., Shimada, T., Kung, H., Nishioka, M., Ikehara, V., and Kuwano, M. 1992. Brefeldin A-resistant mutants of human epidermoid carcinoma cell line with structural changes of the Golgi apparatus. J. Biol. Chem., 267: 11626-11630.

39. Simons, K. and VirTa, H. 1987. Perforated MDCK cells support intracellular transport. EMBO J., 6: 2241-2247.

40. SмIth, D.B. and Johnson, K.S. 1988. Single-step purification of polypeptides expressed in Escherichia coli as fusions with glutathione S-transferase. Gene, 67: 31-40.

41. Sohda, M., Misumi, Y., Fujiwara, T., Nishioka, T., and IKEHARA, Y. 1994. Molecular cloning and sequence analysis of a human $372-\mathrm{kDa}$ protein localized in the Golgi complex. Biochem. Biophys. Res. Commun., 205: 1399-1408.

42. TuCker, S.P., Srinivas, R.V., and Copmans, R.W. 1991. Molecular domains involved in oligomerization of the Friend murine leukemia virus envelope glycoprotein. Virology, 185: 710720.

(Received for publication, June 30, 1997 and accepted, August 24, 1997) 